\title{
Accounting
}

\section{The effect of employee performance through motivation and commitment on government tax officers}

\author{
Atty Tri Juniarti ${ }^{a^{*}}$ and Bayu Indra Setia ${ }^{a}$
}

${ }^{a}$ Faculty of Economics and Business, Pasundan University, Indonesia

\begin{tabular}{l}
\hline C H R O N I C L E \\
\hline Article history: \\
Received March 3, 2021 \\
Received in revised format May \\
112021 \\
Accepted June 52021 \\
Available online \\
June 5 2021 \\
\hline Keywords: \\
Discipline \\
Compensation \\
Competency \\
Motivation \\
Commitment \\
Employee performance
\end{tabular}

\section{A B S T R A C T}

\begin{abstract}
The tax revenue in West Java has not fully realized and developed in accordance with the planned target. In line with reality, the employee performance in the Directorate General of Taxation should greatly determine the amount of tax revenue in West Java. Their performance can be measured based on the terms of quality, namely in achieving predetermined standards. While in the terms of quantity and responsibility, it can be measured based on their achievement on completion targets and following existing work procedures. This research method was carried out descriptively and verified. Assessment of scores on research variables is used as a descriptive method, while Path Analysis method is used both to aim and determine causality between research variables and hypothesis test. The descriptive result showed that Discipline, Compensation, Competency, Motivation, Commitment and Performance are categorized as 'good', but nonoptimal in their achievements. Verificative results showed that there are partially and simultaneously positive and significant effects between Discipline, Compensation, and Competency towards Motivation, both directly and indirectly. The most dominant effect on competency. Also, there are positive and significant effects between motivation and commitment towards employee performance in the West Java Regional I Office of Directorate General of Taxation.
\end{abstract}

\section{Introduction}

Under the 1945 Constitution which states "all taxes and other levies that are coercive are also based on the law". The government, by the Directorate General of Taxation as representative in carrying out their duties, has a main duty to collect domestic revenue from the tax sector that can support the independence of government financing based on tax legislation with a high level of effectiveness and efficiency. These are limited to and based on: 1) Tax Ratio level, Coverage ratio and high compliance ratio; 2) The rise on domestic revenue, which means that taxes should be able to run a major role in financing the deficit of the Revenue and Expenditure Budget; 3) Tax policy should be neutral and non distortion; 4) The ability to support government policy in economy, social and politic; 5) Low cost of collection (Robert, 2001). It is hard for Indonesian tax ratio to rise in terms of percentage, while the other developed countries have already reached $20 \%$ of the tax ratio. Several ways have been carried out to fix this problem: namely by determining tax rate policy, expanding tax base, and improving the facilities and infrastructure at the office of tax service. All of them have not shown optimal results (Brown et al., 2012). Table 1 shows tax ratio data in Indonesia from 2013 to 2017 . Based on the table, we can conclude that during 5 years, Indonesian tax ratio has gone through ups and downs. Indonesia was only able to raise $0.41 \%$ of the tax ratio. This was based and calculated from the previous year's tax ratio, 2017, by $13.30 \%$ minus 2013's tax ratio by $12.89 \%$. We can also find out that Indonesia requires about 4.1 years to raise about $1 \%$ of tax ratio. Meanwhile, other developed countries

* Corresponding author.

E-mail address: attytrijuniarti@unpas.ac.id (A. T. Juniarti) 
have already been successful to raise about $20 \%$ per year. In the other words, Indonesia will have to take 27.5 years and has also been left behind by $6.7 \%$ by other countries. Theoretically, there are several ways for the government to raise tax revenue; namely by determining tax rate policy, expanding tax base, fixing the system of tax collection and utilizing nonoptimal tax potential (Roger, 2000; Choueke \& Armstrong, 2000).

Table 1

Indonesian Tax Ratio level during five years

\begin{tabular}{ccc}
\hline Period & Tax Ratio ( \%) \\
\hline 2013 & 12.89 \\
2014 & 13.58 \\
2015 & 13.92 \\
2016 & 13.50 \\
2017 & 13.30 \\
\hline
\end{tabular}

We also know that the root problem of slow increase in Indonesian tax ratio is caused by tax leakage, as the consequences of 1) the conspiracy between tax-office-insider (state officials) and disobedient taxpayer; 2) the using of false bank validation and the hacking of tax database. To restore the credibility of tax institution, government should consider to 1) fix the attitude of tax state officials and design strict regulation and sanction for those who corrupt tax money; 2) plan a system for collecting tax which can minimize tax leakage including creating a robust tax database with a layered security system and install a bank validation detection tool; 3) conduct regular mutations of tax state officials, so that the government can also break the chain of fraud committed by tax authorities. Tax ratio is a comparison between the amount of tax revenue and gross domestic product in a country. Tax ratio is calculated by percent and shows the extent to which the government's ability to collect tax revenue or re-absorb gross domestic product from the public in the form of taxes. Logically, the higher a country's tax ratio, the better its tax collection performance. A better and optimal performance needs to be done by all members of the organization to realize the mission of Directorate General of Taxation, specially the employees who must have working motivation and positive commitment in their working environment. Therefore, they can also create better performance which can contribute to their institution's success. To reach the purpose of the government, it is important to focus more on the management policy of Human Resources in the organization itself because a good performance of an organization will be determined by the employee's motivation and commitment in the organization. The more positive an employee's motivation and commitment, the better their performance. Otherwise, if the motivation and commitment of the employees are shown in the negative side, it will decrease its organization's performance (Sum et al., 2004). The remuneration compensation given by Directorate General of Taxation provides better results compared to remuneration given to the other civil servants at different institutions (Cooper et al., 2014). Regarding the tax case occurence nowadays, a high level of remuneration has in fact not been able to boost up the employee's performance to work better in the context of earning reliable income source or nation's revenue while employee's motivation is indeed needed in running the job they hold. Fred Luthans (2005) stated that motivation source consisted of 2 motives: intrinsic and extrinsic. Therefore, motivation holds an important role for the organization to create better commitment by the employees themselves. This can be shown in their strong attachment to their work unit so that they can carry out their duties well.

\section{Method}

This research uses a quantitative method, which focuses more on descriptive and explanatory surveys. The descriptive method describes various characteristics of variables being researched while the verification method focuses more on the test of hypothesis.

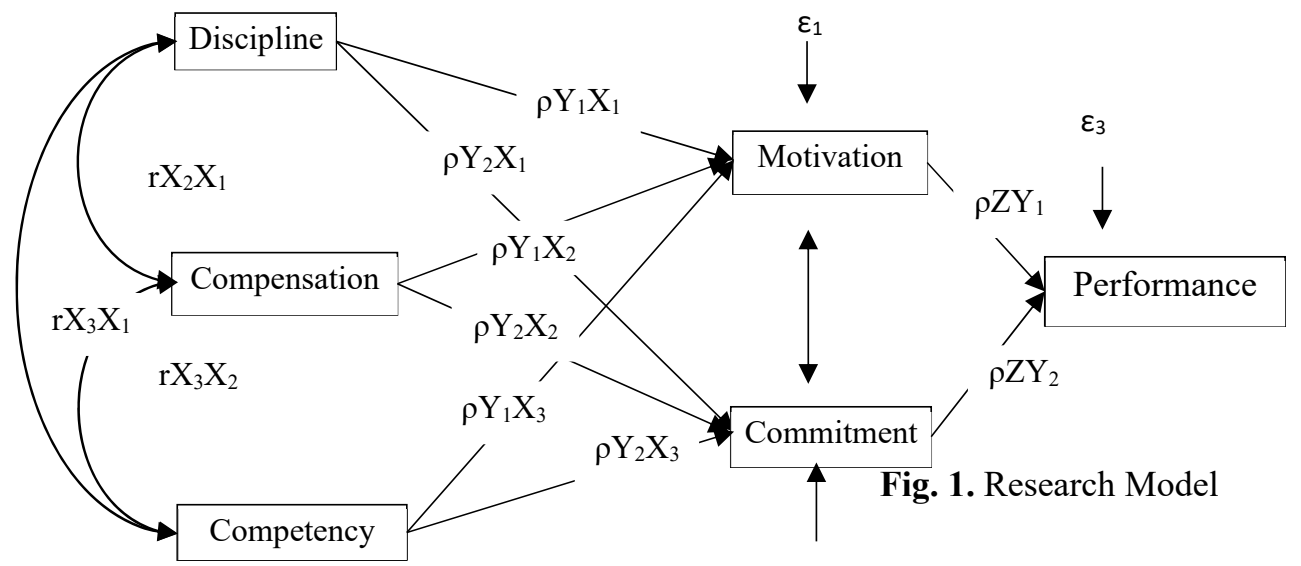


The unit analysis of this research is the officials of Directorate General of Taxation in West Java I Regional Office that is divided into: one Regional Office, one Intermediate Tax Office and sixteen Primary Tax Offices and two Offices of Taxation Services, Counseling and Consultation by the amount of 1.460 employees per January 2019. This research is being observed by collecting samples from all members of the population: one Regional Office, one Intermediate Tax Office, sixteen Primary Tax Offices and two Offices of Taxation Services, Counseling and Consultation. Respondents in this research are lower-to-middle class employees in all work units including Regional Offices and West Java I Intermediate/ Primary Tax Offices. About 217 respondents were taken as samples in this research.

\section{Results and discussion}

\subsection{Discipline}

In fact, working is a form or way for humans to actualize themselves. Working is a tangible form of values, beliefs that are held and a motivation to produce quality work in achieving goals (Kepmenpan No..25/KEP/M.PAN/04/2002). Discipline is an effort of organization management to apply or run the regulation or provision that must be obeyed by every employee without exception. Byars and Rue (2008) defined discipline as behavior, attitude and action in accordance with company's regulations, both written and unwritten.Viewed by the organization perspective, it can be formulated that the obedience of each member of the organization (to all applicable rules inside the organization) is manifested through good attitudes, behaviors and actions to create order, harmony, no disputes, and other good conditions (Newstrom et al., 1985). Based on the descriptive analysis, it can be stated that the employee's discipline showed good results with an average of 3,671 and its deviation standard lies at 0,901 . These are categorized and changed from "good" to "very good" and shows that most respondents have already had "good" discipline. This can also be seen by their punctuality and presence in every condition and situation to work. Therefore, in the context of a presence list, the authorities must not be worried. However, there are still shortages in the use of work equipment based on employees' operational standard which indicates that not all of them use the right procedures in utilizing work equipment. Therefore, the equipment does not last long because of the risk of damage. Meanwhile, in the context of discipline, according to Regulation of Indonesian Republic Number 53/ 2010 concerning Discipline of Civil Servants in lieu of Government Regulation Number 30/ 1980 concerning Regulations of Civil Servants, tax officials who are bound to the Discipline of Civil Servants must obey their responsibility and avoid prohibitions stated in the statutory or official regulation. If this regulation is disobeyed, disciplinary punishment will be given to them. Disciplinary violations are any utterances, writings, or actions of Civil Servants who do not comply with their obligations and/ or violate the prohibition of the provisions of the Discipline of Civil Servants, both conducted inside and outside working hours.

\subsection{Compensation}

Compensation is an important factor which affects people who choose to work in an organization. The organization itself must compete with various kinds of compensation because there are organizational funds spent on compensation-related activities. These activities are important for top management and Human Resource executives to match compensation practices with the goals of the organization.Compensation is a company's binding tool towards their employees, attracting factors for prospective employees and also supporting factors for someone to be an employee. Therefore, compensation has an important factor in running the organization/ company smoothly (Dixit, 2002). Dessler (2006) stated that employee's compensation is all forms of payment or compensation given to the employees based on their work performance. While direct payments are in the form of wages, salaries, incentives, and bonuses. Indirect payments are in the form of financial benefits such as insurance premiums (Dessler, 2006). Davis and Newstrom (1997) stated that if the compensation program is well arranged and formed, it can help a company or organization to reach their purposes and goals, as well as keeping and creating productive employees. Without the giving of adequate compensation, there will be possibilities that the employees will not stay longer in the company. Every company should better form and arrange the compensation program in order to keep creating good reciprocal relations between employees and the company/ institution. Based on the descriptive analysis, compensation showed us a "good" result with an average of 3,220 and its deviation standard of 1,044 so that it is then categorized and changed from "not good" to "very good". This indicates that most respondents have not been satisfied by the compensation they have achieved. By this explanation, the problems do not lay on the organization itself, but on its less-maximum implementation which raises employees' dissatisfaction. Nevertheless, there are still gaps in the average amount of vacation funds based on job position. It indicates that not all of the employees agree with the funds because it is not based on their performance assessment, but on their eagerness. The fund itself must be adjusted based on their job position because it can affect their prosperity.

\subsection{Competency}

In a public or private organization, a competency is highly needed, especially in responding to the organization's purpose and goal. This is needed because there are rapid changes, complex and dynamic problem development and an unexpected future in the society. A competency is a capability based on skill and knowledge supported by working behavior which is in line to its implementation in running the job at the office referring to the predetermined requirements (Sekaran \& Bougie, 2013). According to Government Regulation Number 1/2000, competency is the capabilities and characteristics owned by 
a civil servant in the form of knowledge, behavioral attitudes which are represented in their duties and positions .Building skill and capacity are strategies aimed to increase efficiency, effectiveness and responsiveness in order to improve organizational performance. Its dimensions can be in the form of efforts to develop human resources, organizational knowledge, and institutional reform. In facing the influence of the organization's environment, it is important for us to demand the readiness of the organization's human resources to have the ability to respond to these challenges by demonstrating performance through activities in the field of tasks and work in the field of organization (Gibson, 2003). Based on the descriptive analysis, it is stated that competency showed us "pretty good" results with an average of 3,441 and its deviation standard of 0.925 so that it is considered and changed from "not good" to "very good". It indicates that most respondents have not shown their own skill. However, there is still a lack of average skill. A skill owned by an employee highly supports their capability and individual professionalism. Employees need to work and give their best service to the public, therefore, they also need to work optimally. However, the compensation they have received is not comparable to the service they have provided to the public, so that they are not satisfied with it.

\subsection{Motivation}

Motivation is defined as "mental condition which supports activity and gives energy leading to meet the needs, giving satisfaction or reducing imbalance". Some experts stated that motivation cannot stand alone without the existence of needs and satisfaction, as well as imbalance. (Kreitner \& Kinichi, 2010) These will stimulate and create a higher level of motivation which is able to support and achieve the goal and balance. Motive is an impulse of needs within the employee's self that also needs to be fulfilled so that they can adjust to their environment. While motivation is a condition that encourages employees to be able to achieve the goals of their motives. Motives are not only generated by needs, but also by two separate but related sets of sources. An intrinsic reward is needed to be given to everyone. This gives a feeling of satisfaction and gratitude, and proud of the job they have successfully done. An extrinsic reward comes from an outside individual. Achieving compliments, for example, is one of extrinsic rewards (Jones, 2001). Based on the descriptive analysis, it is stated that motivation showed us "pretty good" results with an average of 3,558 and its deviation standard of 0.934 so that it is considered and changed from "not good" to "very good". It indicates that most respondents have already had good motivation in running their job. This can be seen from their responses about their skill to run the job itself. However, there is still a lack in the average of making policy. Therefore, it also indicates that the employees have not fully been motivated because they assumed that their presence is not really needed. They assume motivation is not always related to compensation but to the affirmation/ recognition from the institution as well. This is the biggest motivation for employees.

\subsection{Commitment}

Sense of attachment to an organization/ institution is needed for employees to be able to survive in their work unit. This sense will last longer and higher compared to those employees who do not have commitment. In Kepmenpan Nomor 25 / KEP / M.PAN / 04/2002, commitment is defined as determination, firmness and promise to realize something that is believed. The definition of commitment basically stresses more on the relationship between employees and their work unit. It raises attitudes that can be seen as a sense of attachment to the philosophy and work units. It also leads employees to firmly and wholeheartedly hold and promise to carry out the tasks in accordance with the principle which has been determined by a group of people or entities that are bound in a cooperation forum to achieve certain goals (Fred, 2005). Based on the descriptive analysis, it is stated that commitment showed us pretty good results with an average of 3,495 and its deviation standard of 0.952 so that it is considered and changed from not good to very good. It indicates that most respondents still lack the work commitment. This can be seen from their responses that stated that every job they have done must be appreciated by appropriate compensation. Therefore, it also indicates that employees are not fully satisfied with the compensation they have received because it is not in accordance with the applicable regulations. In reality, they work under pressure.

\subsection{Performance}

A proper measurement instrument can be further used and done to find out whether the individuals in the organization being led have met the effective criteria or not. The measurement result will be further compared and adjusted to a specific standard. Related to the research being previously done, an individual's role will be very determining so that the explanation about effectiveness will only be discussed in the level of individu (Mimba et al., 2007). Individual effectiveness is also often called employee's individual performance or organization performance in the terms of organization. These are definitions of employee's performance (McShane \& Glinow, 2010). There are lots of differences in defining an employee's performance so that there will never be agreement which one is correct or to be used. Therefore, it may be paradoxically defined. Generally, it can be stated that an employee's performance is a measurement in devoting themselves to the organization to reach the predetermined goals/ purposes. From the point of view of psychological theory, an employee's performance is a process of working behavior to create something proper as its goals. An individual's behavior can be different from the others, based on different situations and conditions. Therefore, it depends on individual factors and its environmental working space. A motivation is the most important thing in the terms of individual factor, while working situation and condition are the most important thing in running best performance. Based on the descriptive analysis, it is 
stated that the employee's performance showed us "good" result with an average of 3,785 and its deviation standard of 0,916 so that it can be considered and changed from good to very good. It indicates that most respondents have already had a good performance. This can be seen from their responses stating that they always have successfully finished their job as instructed punctually. Therefore, it also indicates that employees have already worked maximally to reach the predetermined target, in accordance with the organization vision, even though there are still gaps in the organization itself.

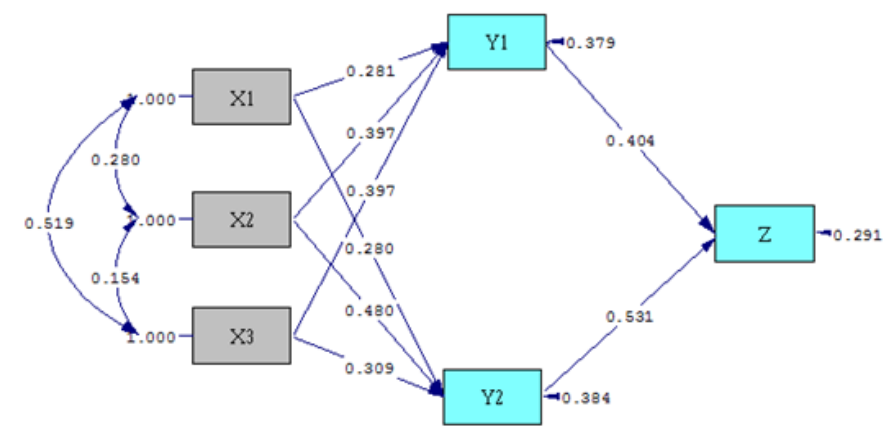

Fig. 2. The effect of discipline $\left(\mathrm{X}_{1}\right)$, compensation $\left(\mathrm{X}_{2}\right)$, and competence $\left(\mathrm{X}_{3}\right)$ toward motivation $\left(\mathrm{Y}_{1}\right)$ and employee performance $(\mathrm{Z})$

Based on the data processing, these are following result of substructure path coefficient 1:

$$
\begin{array}{lll}
\mathrm{Y}_{1}=0.281 \times \mathrm{X}_{1}+0.397 \times \mathrm{X}_{2}+0.397 \times \mathrm{X}_{3}, \text { Errorvar. }=0.379, \mathrm{R}^{2}=0.621 \\
\begin{array}{cccc}
(0.0431) & (0.0279) & (0.0552) & (1.741) \\
5.525 & 9.025 & 8.047 & 10.320
\end{array}
\end{array}
$$

Based on the analysis equation, compensation and competency have similar highest coefficient paths compared to the other variable, namely discipline. According to the equation 1 , it can be stated that:

1. There is a degree of contribution from the variable of working discipline towards working motivation, which is about $0,281\left(\rho_{\mathrm{Y} 1 \mathrm{X} 1}\right)$. Therefore, the more employees have good working discipline, the more they will contribute to working motivation, by 0,281 .

2. There is a degree of contribution from the variable of compensation towards working motivation, which is about 0,397 $\left(\rho_{\mathrm{Y} 1 \mathrm{X} 2}\right)$. Therefore, the higher compensation the employees have received, the more they contribute to working motivation, by 0,397 .

3. There is a degree of contribution from the variable of competency towards working motivation, which is about 0,397 $\left(\rho_{\mathrm{Y} 1 \mathrm{X} 3}\right)$. Therefore, the higher competency owned by an employee, the more they contribute to working motivation, by 0,397 .

4. The influence of variables outside the model is $0.379\left(\rho_{\mathrm{Y} 1} \varepsilon_{1}\right)$.

Based on the table above, the effects (both simultaneously and altogether) of discipline, compensation, and competency towards working motivation are amounted to 0,621 or $62,1 \%$. It states that $62,1 \%$ of variables of motivation can be explained by variables of working discipline, compensation, and competency, while the rest $37.9 \%$ is affected by other variables outside the model that are not being observed.

Table 2

Direct and indirect effects of discipline, compensation and competence toward motivation (\%)

\begin{tabular}{lcccccc}
\hline \multirow{2}{*}{ Variable } & \multirow{2}{*}{ Direct Effect } & \multicolumn{3}{c}{ Indirect effect through } & \multirow{2}{*}{ Total of indirect Effect } \\
\cline { 3 - 6 } & & discipline & Compensation & Competence & & 8.9 \\
Discipline & 7.9 & & 3.1 & 5.8 & 2.4 & 5.6 \\
Compensation & 15.8 & 3.1 & & & 21.3 & 8.2 \\
Competence & 15.8 & 5.8 & 2.4 & 8.2 & 24.0 \\
\hline Total & 39.4 & 8.9 & 5.6 & 62.1 & 22.7 \\
\hline
\end{tabular}

Based on the table above, it is found out that variables of discipline, compensation and competency give effects to working motivation directly and indirectly. The direct effect of the variable of working discipline is about $7.9 \%$ while its indirect 
effect is about $8.9 \%$, passing through the other 2 variables: compensation $3.1 \%$ and competency $5.8 \%$. Direct effect of the variable of working discipline gives a lower effect to working motivation compared to its indirect effect. Therefore, both direct and indirect effects of working discipline give about $16.8 \%$ to working motivation. Compensation is the other variable affecting motivation, both directly and indirectly. The direct effect amounted to $15.8 \%$ while its indirect effect amounted to $5.6 \%$ by passing through the other 2 variables: discipline $3.1 \%$ and competency $2.4 \%$. Direct effect of compensation gives a bigger effect to motivation compared to its indirect effect. Therefore, both direct and indirect effects of compensation give about $21.3 \%$ to motivation. Competency is the other variable affecting motivation, both directly and indirectly. The direct effect amounted to $15.8 \%$ while its indirect effect amounted to $8.2 \%$ by passing through the other 2 variables: discipline $5.8 \%$ and compensation $2.4 \%$. Direct effect of competency gives a bigger effect to motivation compared to its indirect effect. Therefore, both direct and indirect effects of competency give about $24.0 \%$ to motivation. Based on the calculation above, a highest partial/ individual effect to motivation lies on competency about $24.0 \%$, compensation about $21.3 \%$ and discipline about $16.8 \%$. It is concluded that in raising employee's motivation, several ways should be taken in gaining better results; namely, by giving them proper compensation comparable to their job and upgrading their discipline. If all variables can be thoroughly fulfilled, an employee's motivation will also automatically increase. In addition to the three variables above, there are many variables that have an influence on motivation, based on influences outside the model (epsilon) that is equal to $37.9 \%$. It means that motivation is also influenced by other variables outside the research model, that is equal to $37.9 \%$. These variables, for example, refer to promotion, job satisfaction, commitment, spirit, effective communication, etc. Based on data processing, these are following result of substructure path coefficients:

$$
\begin{array}{cccc}
\mathrm{Y}_{2}= & 0.280 \times \mathrm{X}_{1}+0.480 \times \mathrm{X}_{2}+0.309 \times \mathrm{X}_{3}, & \text { Errorvar. }=0.384, \mathrm{R}^{2}=0.616 \\
(0.0586) & (0.0379) & (0.0750) & (3.209) \\
5.486 & 10.856 & 6.222 & 10.320
\end{array}
$$

The results show that compensation has the highest coefficient compared to the other two variables, namely working discipline and competency. According to the results, it can be stated that:

1. There is a degree of contribution from the variable of discipline towards commitment, which is about 0.280 ( $\mathrm{r}_{\mathrm{Y} 2 \mathrm{X} 1}$ ). Therefore, the more employees have good discipline, the more they will commit to their job, by 0.280 .

2. There is a degree of contribution from the compensation towards commitment, which is about 0.480 ( $\mathrm{r}_{\mathrm{Y} 2 \mathrm{X} 2}$ ). Therefore, the higher compensation received by the employees, the more they will commit to their job, by 0.480 .

3. There is a degree of contribution from the variable of competency towards commitment, which is about 0,309 ( $\mathrm{r}_{\mathrm{Y} 2 \times 3}$ ). Therefore, the higher competency owned by the employees, the more they will commit to their job, by 0.409 .

4. The influence of variables outside the model is $0.384\left(\mathrm{r}_{\mathrm{Y} 2} \mathrm{e}_{2}\right)$.

Based on Table 3, the effects (both simultaneously and altogether) of discipline, compensation and competency towards commitment are amounted to 0.616 or $61.6 \%$. It states that $61.1 \%$ of variables of commitment can be explained by variables of working discipline, compensation, and competency, while the remaining $38.4 \%$ is affected by other variables outside the model that are not being observed.

\begin{tabular}{|c|c|c|c|c|c|c|}
\hline \multirow{2}{*}{ Variable } & \multirow{2}{*}{ Direct Effect } & \multicolumn{3}{|c|}{ Indirect Effect through } & \multirow{2}{*}{ Total of Indirect Effect } & \multirow{2}{*}{ Total Effect } \\
\hline & & Discipline & Compensation & Competence & & \\
\hline Discipline & 7.8 & & 3.8 & 4.5 & 8.3 & 16.1 \\
\hline Compensation & 23.0 & 3.8 & & 2.3 & 6.1 & 29.1 \\
\hline Competence & 9.5 & 4.5 & 2.3 & & 6.8 & 16.3 \\
\hline Total & 40.4 & 8.3 & 6.1 & 6.8 & 21.2 & 61.6 \\
\hline
\end{tabular}

Tabel 3

Direct and indirect effects of discipline, compensation and competence toward Commitment (\%)

Based on Table 3, it is found out that variables of discipline, compensation and competency give effects to commitment directly and indirectly. The direct effect of discipline is about $7.8 \%$ while its indirect effect is about $8.3 \%$, passing through the other 2 variables: compensation 3.8\% and competency $4.5 \%$. Direct effect of discipline gives a lower effect to commitment compared to its indirect effect. Therefore, both direct and indirect effects of discipline give about $16.1 \%$ to employee's commitment. Compensation is the other variable affecting commitment, both directly and indirectly. The direct effect amounted to $23.0 \%$ while its indirect effect amounted to $6.1 \%$ by passing through the other 2 variables: discipline $3.8 \%$ and competency $2.3 \%$. Direct effect of compensation gives a bigger effect to the employee's commitment compared to its indirect effect. Therefore, both direct and indirect effects of compensation give about $29.1 \%$ to employee's commitment. Competency is the other variable affecting commitment, both directly and indirectly. The direct effect amounted to $9.5 \%$ while its indirect effect amounted to $6.8 \%$ by passing through the other 2 variables: discipline $4.5 \%$ and compensation 2.3\%. Direct effect of competency gives a bigger effect to an employee's commitment compared to its indirect effect. Therefore, both direct and indirect effects of competency give about $16.3 \%$ to employee's commitment. Based on the calculation above, the biggest partial/ individual effect to employee's commitment lies on compensation about $29.1 \%$, competency about $16.3 \%$ and discipline affecting motivation about $16.1 \%$. It is concluded that in raising employee's commitment, several ways should be taken in gaining better results; namely by giving them proper compensation for their 
job. Therefore, with the proper employee's welfare and better condition, they will also build their own commitments to improve their performance and give their best to the company as well. In the other words, they will work optimally based on their level of discipline and competency. In addition to the three variables above, there are many variables that have an influence on employee's commitment, based on influences outside the model (epsilon) that is equal to $38.4 \%$. It means that commitment is also influenced by other variables outside the research model, that is equal to $38.4 \%$. These variables, for example, refer to promotion, job satisfaction, working spirit, effective communication, etc.

\section{Effects of Motivation and Commitment towards Employee's Performance Simultaneously and Partially}

According to the calculation result of correlation value and path coefficient which has been previously taken, we found out that the effects of motivation and commitment towards employee's performance are shown and described in this following substructure path coefficient 3 and in its equation as well:

$$
\begin{array}{ccc}
\mathrm{Z}=0.404 \times \mathrm{Y} 1+0.531 \times \mathrm{Y} 2, \text { Errorvar. }=0.291, \mathrm{R}^{2}=0.709 \\
(0.0570) & (0.0423) & (1.988) \\
8.637 & 11.360 & 10.320
\end{array}
$$

According to the results, it can be stated that:

1. There is a degree of contribution from the variable of discipline towards employee's performance, which is about 0.398 $\left(\mathrm{r}_{\mathrm{ZY} 1}\right)$. Therefore, the higher motivation, the more they contribute to their performance, by 0.398 .

2. There is a degree of contribution from the variable of employee's commitment towards their performance, which is about $0.523\left(\mathrm{r}_{\mathrm{ZY} 2}\right)$. Therefore, the higher an employee's commitment, the more they contribute to their performance, 0.523 .

3. The influence of variables outside the model is $0.283\left(\mathrm{r}_{\mathrm{Z}} \mathrm{e}_{3}\right)$.

According to the calculation of correlation value and path coefficient which has been previously taken and observed, we found out how big the extent of direct and indirect effects of motivation and employee's commitment towards employee's performance, as described and shown in this following calculation. Based on the equation above, the effects (both simultaneously and altogether) of variables of discipline and employee's commitment towards employee's performance are amounted to 0,717 or $71,7 \%$. It states that $71,7 \%$ of performance can be explained by variables of motivation and employee's commitment, while the rest $28.3 \%$ is affected by other variables outside the model that is not being observed.

\begin{tabular}{|c|c|c|c|c|c|}
\hline \multirow{2}{*}{ Variable } & \multirow{2}{*}{ Direct Effect } & \multicolumn{2}{|c|}{ Indirect Effect through } & \multirow{2}{*}{ Total Indirect Effect } & \multirow{2}{*}{ Total Effect } \\
\hline & & Motivation & Commitment & & \\
\hline Motivation & 15.8 & & 14.3 & 14.3 & 30.1 \\
\hline Commitment & 27.3 & 14.3 & & 14.3 & 41.6 \\
\hline Total & 43.1 & 14.3 & 14.3 & 28.6 & 71.7 \\
\hline
\end{tabular}

Table 4

Direct and indirect effects of Motivation and Commitment toward Performance (\%)

Based on the table above, it is found out that motivation and commitment give effects to employee's performance directly and indirectly. The direct effect of motivation to employee's performance is about $15.8 \%$ while its indirect effect is about $14.3 \%$ by passing through the commitment. Therefore, both direct and indirect effects of motivation give about $30.1 \%$ to an employee's performance. Commitment is the other variable affecting an employee's performance, both directly and indirectly. The direct effect amounted to $27.3 \%$ while its indirect effect amounted to $14.3 \%$ by passing through the motivation. Direct effect of compensation gives a bigger effect to the employee's commitment compared to its indirect effect. Therefore, both direct and indirect effects of compensation give about $29.1 \%$ to employee's commitment. The indirect effect of commitment gives a bigger effect to an employee's performance compared to its direct effect. Therefore, both direct and indirect effects of employee's commitment give about $41.6 \%$ to employee's performance. In addition to the three variables above, there are many variables that have an influence on employee's performance, based on influences outside the model (epsilon) that is equal to $28.3 \%$. It means that employee's performance is also influenced by other variables outside the research model, that is equal to $28.3 \%$. Therefore, motivation and commitment in this model are appropriate to be an intervening variable, or as a medium to relate variables of discipline, compensation, and competency to employee's performance.

\section{Conclusion}

1. discipline, compensation, and competency are considered as independent variables. These following analyses are the results:

a. Discipline consists of 3 dimensions in the scale of agreement: namely discipline in working punctuality, duties and working procedures. It means that the employees in the West Java Regional I Office of the Directorate General of Taxation have already carried out and implemented their discipline very well.

b. Compensation consists of 2 dimensions in the scale of quite appropriate: namely financial and non-financial compensation. It means that the compensation employees have already received in the West Java Regional I Office of Directorate General of Taxation have already been quite appropriate. 
c. Competency consists of 3 dimensions in the scale of agreement: namely knowledge, skills, and abilities. It means that employees in the West Java Regional I Office of Directorate General of Taxation have good competency.

2. Motivation and commitment are considered as intervening variables. These following analyses are the results:

a. Motivation consists of 3 dimensions in the scale of "quite agree": namely behavior, achievement, and team orientation. It means that employees in the West Java Regional I Office of Directorate General of Taxation have sufficient motivation.

b. Commitment consists of 4 dimensions in the scale of agreement: namely understanding, job standard, communication in compensation and evaluation and support. It means that employees in the West Java Regional I Office of Directorate General of Taxation have good working commitment.

3. Employee's performance consists of 3 dimensions in the scale of agreement: namely working quality, working quantity and reliability or responsibility. It means that employees in the West Java Regional I Office of Directorate General of Taxation have good criteria.

4. Working discipline, compensation and competency give positive effects to motivation partially which amounted to $37.30 \%, 22.80 \%$ and $23 \%$ each. They also give positive effects simultaneously which amount to $83 \%$ so that there is influence outside the variables which is amounted to $17 \%$.

5. Discipline, compensation and competency gives positive effects to commitment partially which amount to $38.8 \%$, $24,5 \%$ and $18,7 \%$ each. They also give effects simultaneously which are amounted to $82,1 \%$ so that there is influence outside the variables which is amounted to $17.9 \%$.

6. Motivation and commitment give positive effects to employee's performance partially which are $49,6 \%$ and $44,2 \%$ each. They also give stimulant effect which is amounted to $93,8 \%$ so that there is influence outside the variables which is amounted to $6.2 \%$

\section{References}

Bacal, R. (2001). Performance Management, McGraw Hill Co. USA.

Brown, K., Laue, M., Tafur, J., \& Mahmoed, M. (2012). An Integrated Approach to Strategic Asset Management. Third International Engineering Systems Symposium. Australia: Delfi University of Technology.

Byars, L., \& Rue, L. (2008). Human Resources Management $9^{\text {th }}$ Ed. Boston: Mc.Graw Hill Irwin.

Choueke, R., \& Armstrong, R. (2000). Culture: a missing perspective on small-and medium-sized enterprise development?. International Journal of Entrepreneurial Behavior \& Research, 6(4).

Cooper, D. R., Schindler, P. S., \& Sun, J. (2006). Business research methods (Vol. 9, pp. 1-744). New York: Mcgraw-hill. Davis, K., \& Newstrom, J. W. (1997). Human Behavior. Work (New York: McGraw-Hill Book Company, 1977$), 261$.

Dessler, G. (2006). Human Resources Management. Alabama Prentice Hall.

Dixit, A. (2002). Incentives and organizations in the public sector: An interpretative review. Journal of Human Resources, $37(4), 696-727$

Jones, G. R. (2001). Organizational theory: Text and cases. Prentice Hall.

Kreitner, R. \& Kinichi, A. (2010). Organizational Behaviour. $10^{\text {th }}$ Edition. New York: McGaw Hill Higher Education.

Luthans, F. (2005). Organizational Behavior, $10^{\text {th }}$ edition, Boston. McGraw Hill International edition.

McShane, S., \& Von Glinow, M. (2010). Organizational Behaviour: Emerging Knowledge and Practice for The Real World. $5^{\text {th }}$ Edition. New York, Mc. Graw Hill.

Mimba, N. P. S., Helden, G., \& Tillema, S. (2007). Public sector performance measurement in developing countries: A literature review and research agenda. Journal of Accounting and Organizational Change, 3(3), 192-208.

Sekaran, U., \& Bougie, R. (2013). Research Method for Business. United Kingdom: John Willey \& Sons Ltd.

Sum, C. C., Kow, L. S. J., \& Chen, C. S. (2004). A taxonomy of operations strategies of high performing small and medium enterprises in Singapore. International Journal of Operations \& Production Management, 24(3), 321-345.

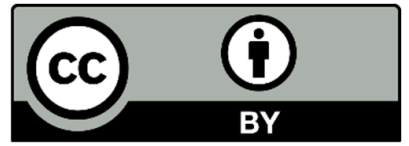

(C) 2022 by the authors; licensee Growing Science, Canada. This is an open access article distributed under the terms and conditions of the Creative Commons Attribution (CC-BY) license (http://creativecommons.org/licenses/by/4.0/). 